\title{
Trends in Training Modern Technicians
}

\author{
Valerii Semenets \\ Department of Metrology and Technical Expertise \\ Kharkiv National University of Radio Electronics \\ Kharkiv, Ukraine \\ valery.semenets@nure.ua \\ Iryna Svyd \\ Department of Microprocessor Technologies and Systems \\ Kharkiv National University of Radio Electronics \\ Kharkiv, Ukraine \\ iryna.svyd@nure.ua
}

\begin{abstract}
The paper considered procedural aspects affecting the quality of modern technicians training as well as practical examples of the implementation of procedures that affect it.
\end{abstract}

Keywords-technical training, cooperation, employers, VHDL, FPGA, MATLAB

\section{INTRODUCTION}

In the modern world, the university seeks to keep up with the times, to follow the trends of scientific and technological progress. Therefore, much attention is paid to the quality of technical specialists graduated from higher educational institutions. The current situation in the labor market also dictates its own conditions and requirements for the quality of technical graduated specialists.

More and more engineers are working at the hardware and software level. Therefore, more in demand are specialists who are fluent in hardware and software. Therefore, technical institutions of higher education need to constantly monitor progressive methods of designing and developing electronic devices and use modern equipment and software in the educational process.

\section{Procedural AsPects Affecting the QuAlity OF TRAINING}

The content of education is dictated by business. Since, they are potential employers. The quality of education depends on the level of cooperation of the university with commercial enterprises.

To improve the quality of technical training, it is useful, starting from junior courses for students, to organize informational meetings with representatives of enterprises, to hold training seminars, trainings, etc. There, students will learn more about the chosen specialty, the requirements of employers, possible areas of study and future professional activities.

One of the ways to improve the quality of technical training is to create specialized laboratories at universities that are equipped with modern equipment. Cooperation with leading specialized enterprises greatly simplifies this process.

Commercial enterprises and companies together with universities create specialized modern laboratories that are

\author{
Liliia Saikivska \\ Department of Microprocessor Technologies and Systems \\ Kharkiv National University of Radio Electronics \\ Kharkiv, Ukraine \\ liliia.saikivska@nure.ua \\ Oleksandr Maltsev \\ Department of Microprocessor Technologies and Systems \\ Kharkiv National University of Radio Electronics \\ Kharkiv, Ukraine \\ aleksandr.maltsev@nure.ua
}

equipped in accordance with the requirements of the labor market. Then the company and the university agree on the areas of study, curriculum, structure of practical and laboratory classes. Next, together with the curator of the company and the university teacher develops teaching materials. If the university has ready teaching materials, they are adapted to the requirements put forward by the employer. The cycles of laboratory and practical work should be logically grouped, have a practical orientation, and correspond to the conditions of a modern employer.

The type of hardware platform is dictated by the employer, as it comes with a complete set of training laboratories. On the plus side, in the modern world, the hardware platforms in the bundle have free software environments for developing and designing devices. It provides universities with licensed software.

Improving the quality of technical training is ensured by coordinating with the employer topics of coursework and certification work. For the acquisition of practical skills students are directed to the Company or to specialized laboratories to carry out the course and certification works.

Important is the organization of production practices in enterprises. That allows students to get practical experience that will ensure their effective work in the future and a decent salary.

The level of practical training of the teaching staff is important. The teacher must comply with current trends, learn the latest equipment, master new software. This is ensured by regular advanced training through internships at leading enterprises in the country and in foreign universities. In this way, the university receives a certified specialist teacher.

\section{PRACTICAL EXAMPLES OF PROCEDURES IMPLEMENTATION}

To improve the quality of technical specialists, a new fundamental technical department of microprocessor technologies and systems (MTS) was created at the Kharkov National University of Radio Electronics.

The Department of MTS carries out educational, methodological, organizational and scientific activities in the field of microprocessor technologies and systems. Teachers of the department for students of technical specialties of 
bachelor level in the cycle of general and specialized vocational training teach the normative discipline "Designing devices on microcontrollers and programmable logic integrated circuits (FPGAs)" with a volume of 10 credits ECTS with such modules:

- "Simulation of digital signals using MATLAB and VHDL" (2 ECTS credits);

- "Microcontrollers" (4 ECTS credits);

- FPGA (4 ECTS credits).

Given the experience of European partner universities, the focus is on practical training. Therefore, for laboratory work allocated $75 \%$ of the total classroom hours.

The department develops the following research areas: designing devices on microcontrollers and programmable logic integrated circuits; digital signal modeling.

For classes at the department, a specialized training laboratory "Designing devices on microcontrollers and FPGAs" was created. The laboratory is equipped with modern hardware and software equipment: personal computers, sets of STM32 DISCOVERY, FPGAs from Xilinx Artix 7, measuring equipment ( Fig. 1). As part of the existing university program of Xilinx (Xilinx University Program, XUP), the Vivado Design Suite software and methodological materials on its use were received for the department. The provided software is used to teach students in laboratory work and in scientific research.

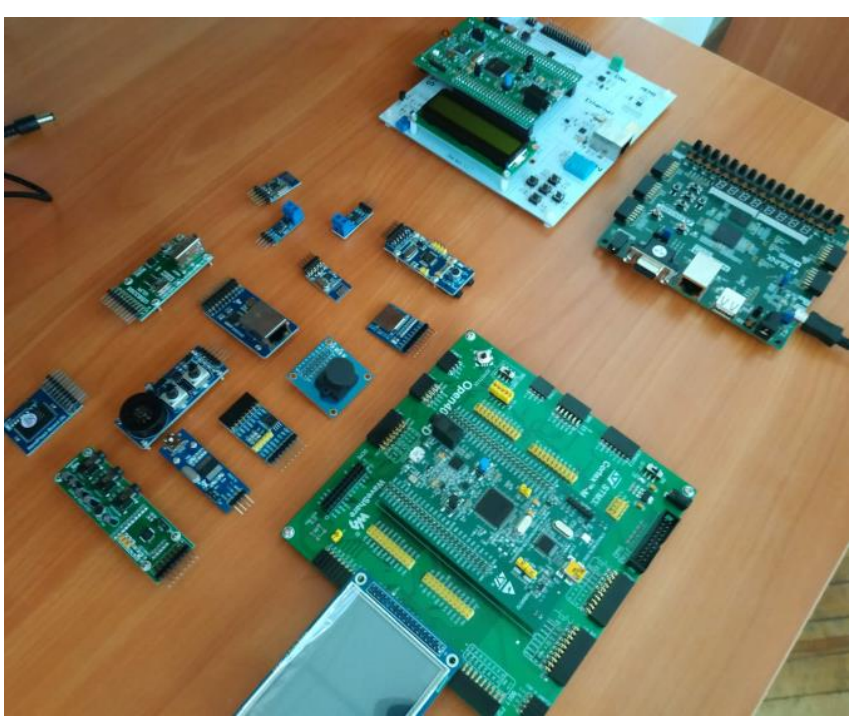

Fig. 1. Laboratory boards.

Regular, staff of the Department of MTS in cooperation with the university administration, the Department of International Cooperation and leading enterprises held informational meetings for students of second and third year students and teachers. It discusses issues of professional competence, requirements of employers for an employee, training courses of companies, opportunities for participation in joint projects, mobile international programs, conditions for advanced training abroad, participation in Erasmus +, Horizon 2020, and others.

\section{CONCLUSION}

Improving the quality of technical training of specialists is an urgent task not only in Ukraine, but also in the world. This is possible with the close cooperation of universities with leading companies - potential employers.

\section{REFERENCES}

[1] V. Semenets, I. Svyd and L. Saikivska, "Methods of improving the quality of preparation of technical specialists", in Engineering education: challendes and developments : materials of the IX International Scientific and Methodological Conference, Minsk, Belarus, 2018, pp. 415-416.

[2] P. Sauh, Innovation in higher education: problems, experience, perspectives: monograph. Edited by Sauh P. Zhytomyr: ZHDU them. I. Franco, 2011, p. 444.

[3] V. Semenets, "Technical aspects for development laboratory base for learning FPGA and microcontroller systems.", in 10th International Conference The Experience of Designing and Application of CAD Systems in Microelectronics, Lviv-Polyana, Ukraine, 2009, p. 145.

[4] O. Avrunin, S. Sakalo and V. Semenetc, "Development of up-to-date laboratory base for microprocessor systems investigation", in 19th International Crimean Conference Microwave and Telecommunication Technology CriMiCo - 2009, Sevastopol, Ukraine, 2019, pp. 301-302.

[5] I. Tarasov. Organization of the educational process in the design of digital devices using an initial level based boards FPGA Spartan-6 company Xilinx. Components and Technologies, 2011,12, pp.10-14.

[6] V. Semenets, V. Kauk, O. Avrunin. "The advanced technology of remote training at the initial process" ["Vprovadjennya tehnologiy dystantsiynogo navchannya u navchalnii protses"], High School, 2009. - No. 5 .- P. 40- 45.

[7] S. Sakalo, V. Semenets and O. Azarhov, High frequencies in medicine (therapy and diagnostics): Teaching manual. Kharkov: KNURE; Collegium, 2005, p. 264.

[8] Semenets V.V. Technology of interconnection of electronic equipment: a university textbook / V.V. Semenets, John Kratz, I.Sh. Nevlyudov, V.A. Palagin. - X.: ed. SMIT, 2005 - 432 p.

[9] Svyd I.V., Litvinenko O.V., Bilotserkivets O.G. Features of designing digital devices based on Xilinx FPGA in CAD Vivado HLx Design Suite. // Specialized Exhibition «KharkivProm Days. Production and efficiency ". Collection of materials of the forum section "Automation, electronics and robotics. Development Strategies and Innovative Technologies ». - Kharkiv, KNURE, Exhibition Company ADT, 2019. - P. 43-44.

[10] V. Semenets, V. Levikin and V. Sayenko, "Research and analysis of the didactic policy of the university in the training of specialists in information technology", Automated control systems and devices, vol. 175, pp. 4-14, 2018.

[11] O. Avrunin, O. Kruk, T. Nosova and V. Semenets, "Technical aspects of the development of virtual laboratory works on technical educational disciplines", Open Education, vol. 3, pp. 11-17, 2008.

[12] V. Kobzev, V. Semenets and V. Filatov, "Components of the information system for monitoring the quality of education in Kharkov National University of Radio Electronics", in 7th Int. scientific and technical conf. Information systems and technologies (IST-2018), Kharkiv-Koblevo, 2018, pp. 51-54. 